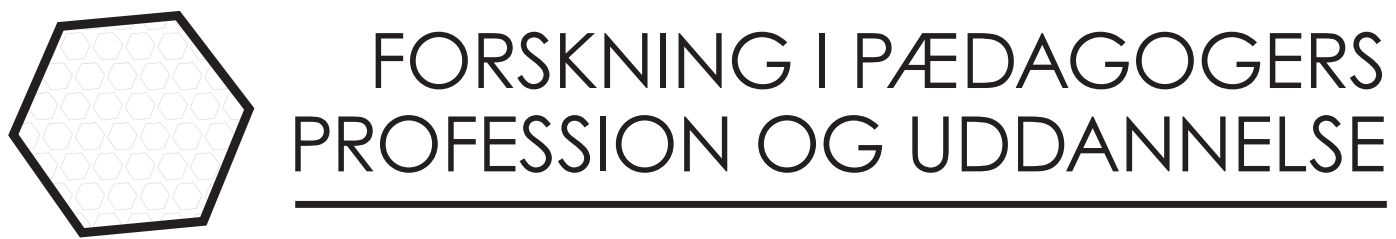

\title{
Pcedagogstuderende kan nå til forståelse af det almene gennem personlige fortcellinger med afscet i privatfotos
}

- resonans, dannelse og etik

\section{Andreas Nielsen}

lektor på pædagoguddannelsen på Professionshøjskolen Absalon andn@pha.dk 


\title{
Resume
}

I denne artikel undersøger jeg, hvordan studerende på pædagoguddannelsen kan udvikle et kropsligt stemt og etisk retningsgivende sprog ved at fortælle om egne livserfaringer med afsæt i privatfotos. I analysen viser jeg, hvordan abstrakte ord som fx fællesskab, livskvalitet, frihed og dannelse bliver stemt af de studerendes egne livserfaringer, når de i undervisningen med afsæt i privatfotos fortæller om væsentlige hændelser i deres eget liv. Den kropsfænomenologiske analyse viser, at stemtheden kommer til udtryk i deres kropssprog, fx i stemme og ansigtsmimik, og forplanter sig til tilhørerne gennem interkropslig resonans. Dermed synes der i undervisningsrummet at opstå en form for samstemthed, som giver den faglige samtale mening og substans.

På baggrund af analysen argumenterer jeg for, at pædagogstuderende i højere grad, end det nu er tilfældet, bør have mulighed for at øve sig i at være til stede i ordene og i samtalen som personer; som subjekter, dvs. med deres egen krop og historie. Det gør det også muligt at erfare, at forståelse hermeneutisk betragtet er noget, vi kommer til forskellige steder fra, fx har vi hver især mødt og oplevet fænomenet fællesskab på forskellige måder. Det er ikke bare en vigtig erkendelsesmæssig pointe, men også en etisk og dannelsesmæssig: At undersøge og tage stilling til, hvad de værdier, som ordene er behæftet med, egentlig betyder, er også forbundet med at undersøge og lytte til, hvad de betyder for andre.

\begin{abstract}
Pedagogy students can reach an understanding of the general through personal stories based on private photos - Resonance, education and ethics

In this article, I investigate how pedagogy students can develop a bodily founded and ethically guiding language by telling about their own life experiences based on private photos. I analyse how abstract words such as community, quality of life and freedom are affectively attuned by the students' own life experiences. The phenomenological analysis shows that this affective attunement is expressed in their body language, for example in their voice and facial expressions, and spreads to the audience through inter bodily resonance. Thus, a form of shared affective attunement seems to arise in the classroom, which gives the academic conversation meaning and substance. Also, the students seem to get the opportunity to practice being present in words and in conversation as persons; as subjects, i.e. with their own body and history.
\end{abstract}

\section{Nøgleord}

Pædagogik, fænomenologi, hermeneutik, stemthed, resonans og dannelse

\section{Keywords}

Pedagogy, phenomenology, hermeneutics, affective atunement, resonance and education 
"Søg derfor redning fra de almene motiver $i$ de motiver Deres egen hverdag frembyder [...] brug tingene i Deres omgivelser når de vil udtrykke Dem, billeder fra Deres drømme og genstande fra Deres erindring. Hvis Deres hverdag forekommer Dem fattig, så anklag ikke den; anklag Dem selv, sig til dem selv at De ikke er digter nok til at fremkalde dens rigdomme; for den skabende er der ingen fattigdom og intet fattigt ligegyldigt sted."

Rainer Maria Rilke, Breve til en ung digter.

\section{Indledning}

I denne artikel præsenterer jeg fund fra en undersøgelse af et nyt undervisningsgreb, som er udviklet på pædagoguddannelsen på Professionshøjskolen Absalon siden efteråret 2018. Jeg kalder undervisningsgrebet Pædagogiske billeder. Essensen af undervisningsgrebet er, at de studerende forsøger at nå til en dybere eksistentiel forståelse af begreber som fx livskvalitet, identitet og fællesskab ved at reflektere over dem med udgangspunkt i personlige fortællinger med afsæt i privatfotos. Formålet er at gøre samtalen mellem studerende og undervisere kropsligt stemt af oplevelser i den livsverden, hvori ord og begreber i et hermeneutisk fænomenologisk perspektiv henter deres mening. Dette både for at undgå, at samtalen bliver for abstrakt og indholdstom, og de studerende bliver fremmede over for begreberne. I stedet må de have mulighed for at øve sig $i$ at være til stede i ordene og i samtalen som personer; som subjekter, dvs. med deres egen krop og historie.

Formålet med artiklen er altså at undersøge, hvad der sker i undervisningen af pædagogstuderende, når man arbejder med Pædagogiske billeder. Hvilken betydning har det for måden, hvorpå de taler, samtaler og forstår centrale begreber, at det sker med afsæt i personlige fortællinger illustreret gennem privatfotos? Det vil fremgå, at begreber som stemthed og kropslig følelsesmæssig resonans (Jørgensen, 2015; Rödel \& Brinkmann, 2018; Fuchs, 2013, 2016, 2016b) er centrale for analysen.

Baggrunden for artiklen er bl.a., at der er behov for at undersøge, hvordan man i pædagogers uddannelse kan supplere kognitive, refleksive, akademiske videnformer med en mere kropsligt fornemmende praktisk sans (Togsverd \& Rothuizen, 2020). Der er i den forbindelse blevet argumenteret for at vende blikket mod den livsverden, hvori de studerende har gjort deres første og grundlæggende kropslige erfaringer med menneskelige relationer (Bille, Nielsen, Jørgensen \& Holand, 2017; Nielsen, 2017). I et eksistentielt fænomenologisk perspektiv er koblingen til de studerendes egen livsverden, fx gennem arbejdet med livshistorier, en forudsætning for en substantiel forståelse af begreber som fx tillid, omsorg og anerkendelse; en forståelse, der henter sin mening gennem den kropslige stemthed, der opstår i mødet med fænomenerne (ibid.). 
Forbindelsen mellem de studerendes personlige livserfaringer og forståelsen af det alment menneskelige udgør den dannelsesmæssige dimension, som flere har kritiseret for at stå for svagt i uddannelsen af pædagoger (Schmidt, 2007; Rothuizen, 2015; Togsverd \& Rothuizen, 2013) og på videregående uddannelser mere generelt (Lindseth 2009, s. 26). Eksempelvis er den pædagogstuderendes alsidige personlige udvikling, som historisk set har spillet en vigtig rolle i pædagoguddannelsen, elimineret i de seneste bekendtgørelser. Blandt internationale forskere har Gert J.J. Biesta (fx 2018) kritiseret en uddannelsestendens til at overbetone kvalificering og socialisering på bekostning af subjektivering, forstået som den dannelsesproces, der igangsættes af et personligt møde med verden.

For så vidt at muligheden for at gøre erfaringer er givet i og med vores kropslighed, som muliggør en sansning af og dermed i grundlæggende forstand et møde med verden og andre mennesker, er dannende erfaringer også kropsligt funderede (Knudsen, 2008). Man må derfor have kroppen med, hvis man vil modvirke en "eksistensiell stumhet" (Løvlie, 2009, s. 36), som kan opstå i et uddannelsessystem, der ikke interesserer sig for den studerendes liv og baggrund og underkender personlige erfaringer og betragter dem som noget, der ikke hører hjemme i en akademisk sammenhæng, fordi de tilsyneladende udgør en alt for ufaglig og subjektiv vinkel:

"Slik kan akademiske studier 'loere'studentene at de skal stenge av for egne livserfaringer, noe som forer til at de blir 'faglige' på en upersonlig måte i møte med pasientene. Dermed utnyttes ikke den ressurs til innsikt som egne livserfaringer utgjør, [...]" (Lindseth, 2009, s. 25).

Disse betragtninger synes at være i overensstemmelse med en kritisk-konstruktiv didaktik (Schou 2013, s. 312 ff.), der søger at undgå, at læring bliver en ren socialiseringsproces med afsæt i udvendige mål, men også har som sit mål, at den studerende får mulighed for at tilegne sig stoffet på en selvstændig måde, hvor stoffet antager en mening, fordi den studerende har mulighed for at relatere det til egne personlige livserfaringer.

\section{Beskrivelse af undervisningsgrebet Padagogiske billeder}

Jeg har sammen med min kollega, Mostafa Yamil, siden efteråret 2018 gentaget arbejdet med Pædagogiske billeder med fem årgange af studerende. Brugen af Pædagogiske billeder knytter sig til en lille modulopgave på modulet Livskvalitet, identitet og fællesskab på specialiseringen Social- og specialpædagogik. Modulet varer seks uger og udgør den syvende af uddannelsens i alt 10 etaper. Et uddrag fra opgavebeskrivelsen har følgende ordlyd:

"Opgaven tager udgangspunkt $i$ arbejdet med poedagogiske billeder. Poedagogiske billeder kan fx voere fotografier, malerier, videoklip, en lille hverdagsfortoelling, et digt eller et maleri. 
Når man som professionel og menneske $i$ det hele taget vil forstå og skabe mening $i$ tilvoerelsen har man ikke nok $i$ ord, fagbegreber, tal og statistikker. Man må også anvende cestetiske udtryksformer. Astetiske udtryksformer kan nemlig hjolpe én til at leve sig ind, hvad det fx vil sige at voere hjemløs, uden for foellesskabet og ensom. Toenk bare på udtrykket, at et billede siger mere end 1.000 ord, eller hvordan vi kan opleve, at musik $u d t r y k k e r$ vores følelser på en langt mere nuanceret måde, end vi kan gøre $i$ ord.

Meningen med de paedagogiske billeder er altså, at I ved hjoelp deraf skal forsøge at danne jer en levende forståelse af de faglige og teoretiske begreber, som I bliver proesenteret for $i$ undervisningen. En levende forståelse af fx et foenomen som fallesskab får vi også gennem billeder af forskellig art, ikke gennem faglige og teoretiske begreber alene.

Vi har alle billeder og personlige fortcellinger, der kan kobles til pœedagogiske emner som fx: identitet, foellesskab, livskvalitet, trivsel, udvikling, loering, relationer, inklusion og eksklusion, normalitet og afvigelse, diagnoser, marginalisering, etik, sundhed, magt og afmagt, medborgerskab, selvbestemmelse, kommunikation, konflikter og samarbejde."

Den nœeunte roekke af fagbegreber er taget fra modulets ved bekendtgørelsen fastsatte laeringsmål. Som det fremgår, skal billeder forstås multimodalt. Derfor må de studerende også gerne voelge et digt, en novelle, et eventyr eller et klip fra en tv-serie. Hver uge skal de studerende voelge nye billeder og begrunde deres valg: Hvordan hoenger de sammen med modulets centrale temaer og begreber, og hvad siger de derom? I løbet af de første uger af modulet kan de studerende anvende Poedagogiske billeder, som de ikke selv har produceret. Til fremloggelsen skal de studerende anvende Poedagogiske billeder, der er produceret af dem selv til lejligheden eller fx et billede fra deres eget fotoarkiv. Typisk voelger de studerende privatfotos, fx af oplevelser med familie og venner, med naturen, fotografier fra rejser eller bestemte livsperioder og fotografier, der minder dem om vigtige livsvalg eller om scerligt gode eller sucere oplevelser."

Grundlaget for den afsluttende fremlæggelse af Pædagogiske billeder er en lille skriftlig opgave (minimum 2.400 tegn), hvori der skal indgå et Pædagogisk billede for hvert af studiegruppens medlemmer. I opgaven og til den mundtlige fremlæggelse præsenterer de baggrunden for deres valg af billeder, billedernes personlige betydning for dem og deres relation til modulets faglige temaer og begreber, $\mathrm{fx}$ livskvalitet, identitet og fællesskab, der som sagt er titlen på modulet. Efter fremlæggelsen er ordet frit til en dialog om de indtryk og tanker, som fremlæggelsen har affødt. Under dialogen sidder studerende og underviser rundt om et bord, så samtalen også kommer til at foregå mellem de studerende og ikke alene mellem underviser og enkelte studerende på skift. Det er med andre ord vigtigt, at de studerende taler med hinanden og ikke kun med underviseren.

Undervisningsgrebet er inspireret af Dorte Jørgensens æstetiske erfaringsbegreb. Når de studerende med afsæt i privatfotos knytter almenbegreber som fx livskvalitet og fællesskab til personlige fortællinger, er det med hensigten at skabe en helhedserfaring af sprog, fotografier og en kropslig stemthed, der forener intellekt; analytiske og begrebslige aktiviteter, sanser, følelser, fornemmelser og anelser (Jørgensen, 2006, s. 118; 2015). Fænomenologisk betragtet indbefatter den æstetiske erfaring en følelsesmæssig kropslig stemthed af det fænomen, vi står over for (Jørgensen, 2015; Austring \& Sørensen, 2010, s. 11). 


\section{Empirisk materiale og analysemetode}

Det empiriske materiale stammer fra to af de fem gennemførte undervisningsforløb og består af de studerendes skriftlige opgaver, inkl. privatfotos, deltagerobservationer i undervisningen, de studerendes evalueringer og mere uformel løbende feedback. På hvert af undervisningsforløbene var der ca. 20 studerende. På det ene af de to forløb har jeg desuden foretaget to lydoptagelser under de studerendes fremlæggelser af deres opgave med Pædagogiske billeder, som i næsten alle tilfælde bestod af privatfotos.

Undersøgelsen som helhed er kvalitativ og eksplorativ, idet jeg går i dybden med et afgrænset empirisk felt med henblik på "at indsamle livsnære og nuancerede informationer og at tolke disse i forhold til deres kontekst" (Harboe, 2006, s. 33). Målet er at opdage og undersøge specifikke kendetegn ved undervisning med Pædagogiske billeder: Hvad sker der i undervisningen, når undervisere beder studerende om at relatere almene begreber som fx livskvalitet og dannelse til personlige fortællinger og vigtige livsbegivenheder, som de illustrerer gennem privatfotos?

Det trådte i det empiriske materiale tydeligt frem, at både dem, der fortalte og viste billeder, og tilhørerne; de medstuderende og jeg selv, blev følelsesmæssigt berørt og stemt. Stemtheden kunne jeg både registrere og undersøge i deltagerobservationerne og lydoptagelserne. Under deltagerobservationerne så, hørte og fornemmede jeg først og fremmest de studerendes følelsesmæssige stemthed i deres ansigtsudtryk, fx deres blik, og i deres stemme. Ting, der særligt fangede min opmærksom, skrev jeg små noter til. Lydoptagelserne gjorde det muligt at vende tilbage til og dykke ned i bestemte hændelser og forløb, fx kunne jeg genafspille bestemte passager med henblik på at undersøge tonefald, berørtheden i en stemme og den stemningsmæssige dimension i de studerendes udvekslinger, fx hvordan de blev berørte af og afstemte sig i forhold til hinandens fortællinger, hvad jeg selvfølgelig også kunne observere i undervisningen. I transskriberingen af det auditive materiale noterede jeg de stemningsmæssige aspekter, så jeg kunne sammenholde det, der blev sagt, med måden, det blev sagt på. De skriftlige opgaver kunne jeg foruden de mundtlige fremlæggelser bruge til at forstå, hvordan de studerende knyttede almenbegreberne til deres personlige fortællinger og privatfotos, som var indsat i opgaven.

Idet stemninger ikke foreligger som objektive direkte observerbare størrelser, har jeg metodisk ladet mig inspirere af Severin Sales Rödels og Malte Brinkmanns (2018) kropsfænomenologiske videoanalyse, hvor forskeren bruger sin egen kropslige følelsesmæssige respons som kilde til forståelse. I denne optik er forskerens subjektivitet og kropslige og emotionelle indlejrethed i situationen en væsentlig forudsætning for forståelse (Gallagher, 2011). Min metode er også inspireret af Thomas Fuchs (2013, 2016, 2016b) teori om interkropslig resonans. Fuchs peger i sin forskning på, at forståelsen af andre involverer et meningslag, der eksisterer som en form for interkropslig resonans eller interaffektivitet: Den andens 
følelsesmæssige tilstand skaber en følelsesmæssig resonans hos modparten, som uden bevidsthedens mellemkomst dermed opnår en umiddelbar kropslig fornemmelse for intentionen og følelserne bag det, som modparten forsøger at sige.

Det er med det metodiske udgangspunkt, at jeg i analysen af deltagerobservationerne og lydoptagelserne ikke bare lyttede til, hvad der blev sagt, men også til, hvordan det blev sagt; altså fx tonefald og kropssprog, som jeg fortolkede i lyset af den følelsesmæssige resonans, det skabte i mig selv. Man kan også sige, at jeg ikke blot lyttede til ordene, men til kroppen bag dem - den krop, hvormed de studerende har gjort personlige erfaringer med de fænomener, som de forsøger at forstå.

Med afsæt i det empiriske materiale vil jeg i det følgende give konkrete eksempler på, hvordan berørtheden og stemtheden viste sig under fremlæggelserne af de Pædagogiske billeder og spillede ind på forståelsen af centrale faglige begreber og perspektiver. ${ }^{1}$ Løbende reflekterer jeg over, hvilken betydning stemtheden har for de studerendes dannelse. I eksemplerne har jeg skiftet alle navne ud med fiktive navne, og jeg har indhentet tilladelse til brug af det auditive materiale, uddrag fra opgaver og privatfotos.

\section{At blive stemt og berørt for at finde sin egen stemme}

Et fotografi viser en gruppe nybagte studenter, der holder om hinanden og griner og skærer ansigter og virker euforiske og glade. Til fremlæggelsen fortæller Line: "... billedet viser noget om venskab og foellesskab og identitet, fordi vi jo også stod overfor at skulle trœffe nogle valg om, hvad vi så skulle med vores liv (...)"

Fotografiet gemmer også på en anden historie. Et år efter billedet blev taget, kørte den unge mand i gruppen på billedet galt på sin motorcykel og mistede sin hukommelse. Efter ulykken kunne han ikke huske, hvem han var. Line fortæller, at han forsøgte at skabe en forbindelse til sit gamle jeg ved at "kigge på gamle sms-beskeder og billeder og fortcellinger fra venner og familie, om hvem han ligesom er, så prøver han at skabe sig selv på ny og stadigvoek holde fast $i$, hvem han var før. Og det synes jeg også har noget med livskvalitet at gøre. Det har sat tingene lidt i perspektiv for os, der kender ham, at man toenker lidt mere over, hvad livet betyder, og hvad det skal indeholde."

Som forsker registrerer jeg Lines stemthed. Jeg kan se og høre, at hun er berørt og følelsesmæssigt stemt af historien, og hendes berørthed forplanter sig til os, der sidder og lytter, så der opstår en form for samstemthed. Den kommer til udtryk i små bekræftende lyde fra tilhørerne, at alle har blikket opmærksomt rettet mod dem, der fortæller - og ikke kigger ned i deres skærm, og at tilhørernes mimik

1 Selvom der i analysens empiriske materialer indgår fotografier, betragter jeg ikke min undersøgelse som en form for visuel etnografi (Rasmussen, 2018). Selvfølgelig giver fotografierne mulighed for at undersøge, hvordan verden ser ud fra de studerendes perspektiv, men det er ikke som sådan det, der er artiklens formål. Formålet er ikke at undersøge, hvad de med fotografierne siger om fx dannelse eller fællesskab, men hvordan de gør det, og hvilken betydning det har, at det sker med afsæt i personlige fortællinger illustreret gennem privatfotos. 


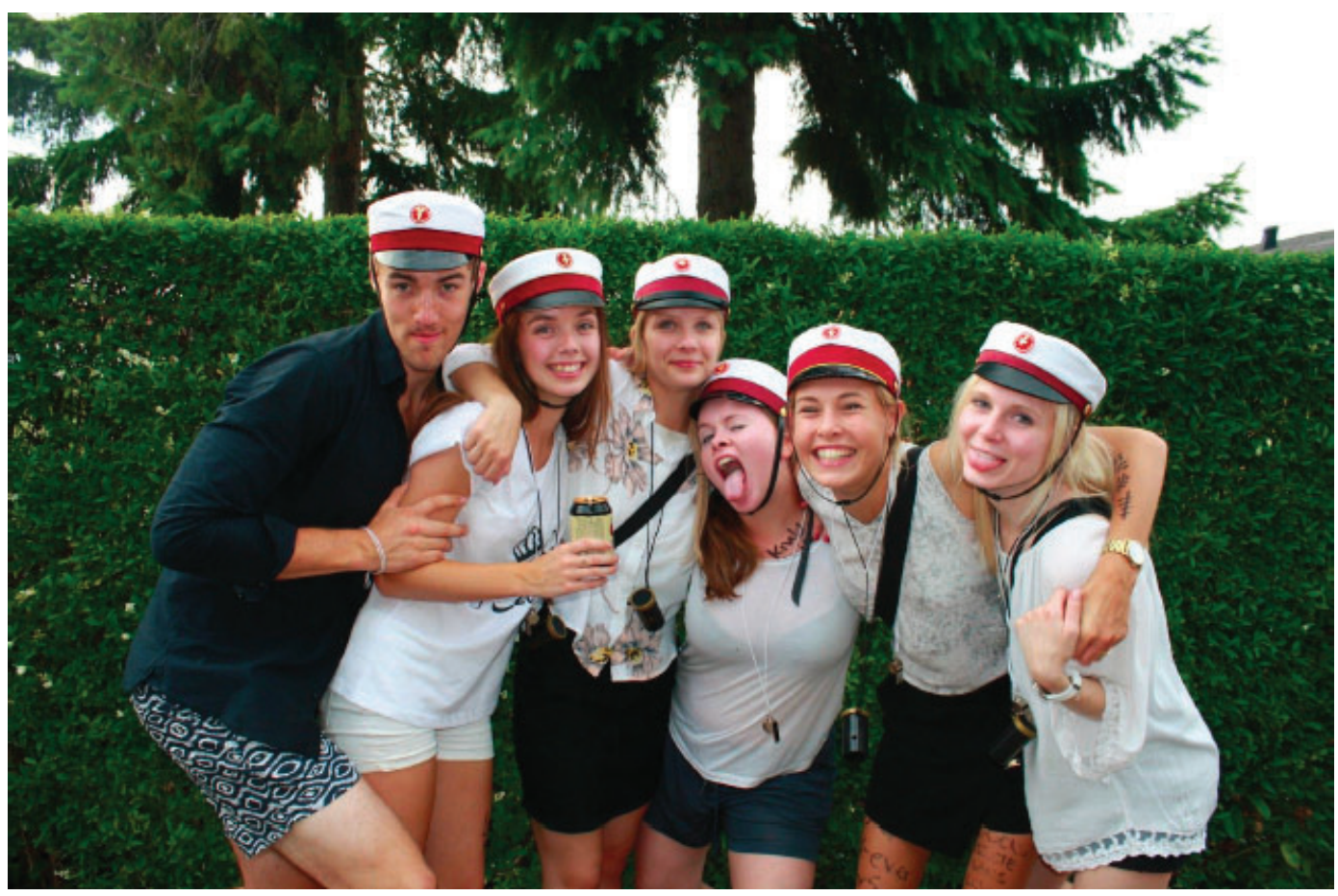

og ansigtsudtryk spejler fortællerens og synes at udtrykke de samme grundlæggende stemninger og følelser. Ansigterne og de studerendes kropsholdninger viser indlevelse og åbenhed over for det, de hører og ser. De viser med deres kropsholdning, at de tager det alvorligt.

Line har skrevet opgaven sammen med Annette, som fortæller om det næste billede.

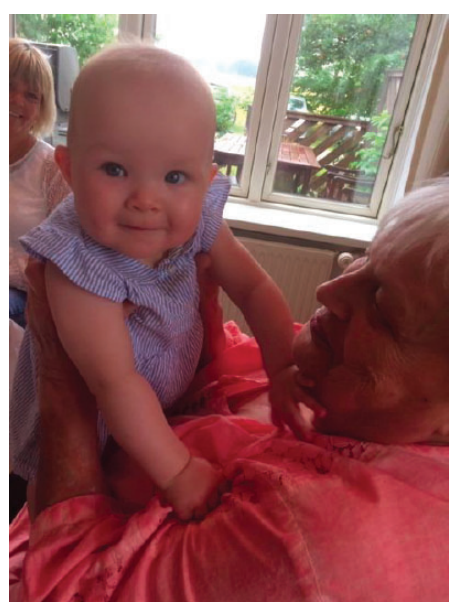

I opgaven har Annette bl.a. skrevet:

"Billedet viser familiens celdste (Vivian) og yngste (Linea) $i$ samspil. Oldemors kcerlige blik på lille Linea-og lille Linea som $i$ oldemors trygge faun kigger nysgerrigt og opmoerksomt ud $i$ verden. Ens identitet er foranderlig og oendres livet igennem (...)"Videre i opgaven forklarer Line og Annette sammenhoengen mellem billederne: "Begge billeder illustrerer også livskvalitet, idet at mennesket skabes og udvikles $i$ samspillet med andre - og at samvor med andre derfor er en afgørende faktor for glcede $i$ livet. Billederne siger også noget om identitet, på det ene billede fra de første spoede skridt $i$ at voere menneske. Hvem er man, når man fødes - og hvor skal man hen? Til de sidste skridt i livet, hvor man måske noermere reflekterer over, hvem man så har voeret? På det andet billede ser vi et nedslag $i$ et liv, hvor man netop står på vejen til at skabe sig en identitet for resten af ens liv. Hvilken vej skal man gå i livet, og hvem vil man vare?" 
Efter Lines og Anettes fremlæggelse sætter de studerende selv ord på berørtheden.

Lise: "I kom med nogle meget personlige billeder, også hvor I blev berørt." Line: "Ja, jeg blev mere berørt, end jeg lige havde regnet med." Der opstår en lille pause, som får nogle til at grine lidt. Jeg siger, at det er o.k., at vi ikke lige ved, hvad vi skal sige: "Folk sidder måske bare lige og tager oplevelsen ind." Mette fortscetter: "Jeg tror også bare, at det er så personligt, det gør, at jeg endnu bedre kan relatere til det. Det gør også, at det giver endnu bedre mening med alle de her fagbegreber, det er lettere at koble det på." Jeg italescetter forbindelsen mellem livets sårbarhed og skønhed, og jeg fornemmer på de studerende gennem deres kropsprog og deres stemmer, at det voekker genklang. Line: "Ja, og vi har også kun det ene liv."

Min fortolkning af eksemplet viser, at de studerende er følelsesmæssigt stemte og berørte af deres personlige livserfaringer, når de fortæller med afsæt i deres privatfotos. Denne stemthed sidder i kroppen på dem, fx tegner den sig i deres ansigter og former deres kropsholdninger, og i særdeleshed lyder den i deres stemmer. Jeg kan altså se og høre, at de er berørte af personlige livsindtryk. På tilhørernes reaktioner, kropslige som sproglige, kan man se og høre, at denne berørthed forplanter sig til dem. Med afsæt i Fuchs begreb om interkropslig resonans vil jeg argumentere for, at det hjælper tilhørerne med ikke bare kognitivt og rent intellektuelt, men også følelsesmæssigt at forstå og fornemme meningen med det, der bliver sagt. Dermed forenes intellekt og følelser i en helhedsorienteret tænkning (Jørgensen, 2006, s. 118; 2015).

Hartmut Rosas begreb om resonans synes også relevant (Rosa, 2016). I relation til undervisning og uddannelse fremhæver Rosa (2017, s. 27), at det ikke handler om at beherske verden, men om at blive "eksistentielt berørt" af den; at blive bevæget og sat i svingninger. Når man er således berørt, taler verden til én på en måde, som fordrer, at man svarer med sin egen stemme. Så handler det ikke længere kun om at svare rigtigt, men om at svare oprigtigt. Faktisk giver tanken om et rigtigt svar; en rigtig definition af fx ordet dannelse, slet ikke mening, fordi man må svare med afsæt i den måde, man som partikulært og enestående individ i sit eget liv er blevet berørt af sagen på. Når man forsøger det, finder man sin egen stemme: Måden man siger ordene på; hele kroppen bag ordene, er nemlig på en helt unik måde stemt af konkrete erfaringer med fx, som de følgende eksempler viser, at være i eller uden for fællesskaber, at være ensom, at komme tæt på døden.

Denne vægtning af stemtheden og berørtheden kan sættes i forbindelse med Biestas begreb om subjektivering (Biesta 2013, s. 170). Subjektivering hænder i situationer, hvor det ikke (kun) er vigtigt, hvad der siges, men hvem der siger det (Biesta, 2011, s. 100; Nielsen, 2019, s. 100), altså at den talende er til stede som et unikt og uerstatteligt individ med sin egen stemme - og siger noget, som kun kan siges på lige netop den måde, af lige netop den person. I sådanne situationer danner den studerende "sin egen uforvekslelighed og kendelige stemme" (Rosa, 2017, s. 32). Den mulighed foreligger kun, fordi "ordene bliver til som udtryk for de 
indtryk, som vores tœenkende kroppe modtager og skaber gennem deres interaktion med verden" (Kirkeby, 2016, s. 55).

At tale med sin egen stemme må ikke forveksles med en form for ekspressivisme (Biesta, 2017, s. 38) eller konstruktivisme (Biesta, 2017, s. 108). Det er kun muligt at tale med sin egen stemme, når man er stemt og berørt af noget ude $\mathrm{i}$ verden. Verden er ikke bare et intenderet objekt, dvs. resultatet af vores ensidige rettethed mod og hensigter med den. Verden kalder på vores opmærksom, gør indtryk på og bevæger os - får os til at vende os, dreje hovedet, svinge og danse, ryste af latter og gråd: "Our relationship with the world is at a very basic level not a matter of intention but rather of affection" (Biesta, 2017, s. 39). ${ }^{2}$

Der er flere eksempler i materialet på, at der ikke bare blev lyttet til det, der blev sagt, men til måden, det blev sagt på; til stemningen, til tonelejet, til kroppen og personen bag ordene. Eksempelvis da Søren med afsæt i et holdbillede fra hans studietid på Idræt og Sundhed fortalte om hans "mest ensomme tid", og da Susanne fortalte med afsæt i et privatfoto af hende selv i motorcykeldragt foran en kirkegårdsmur.
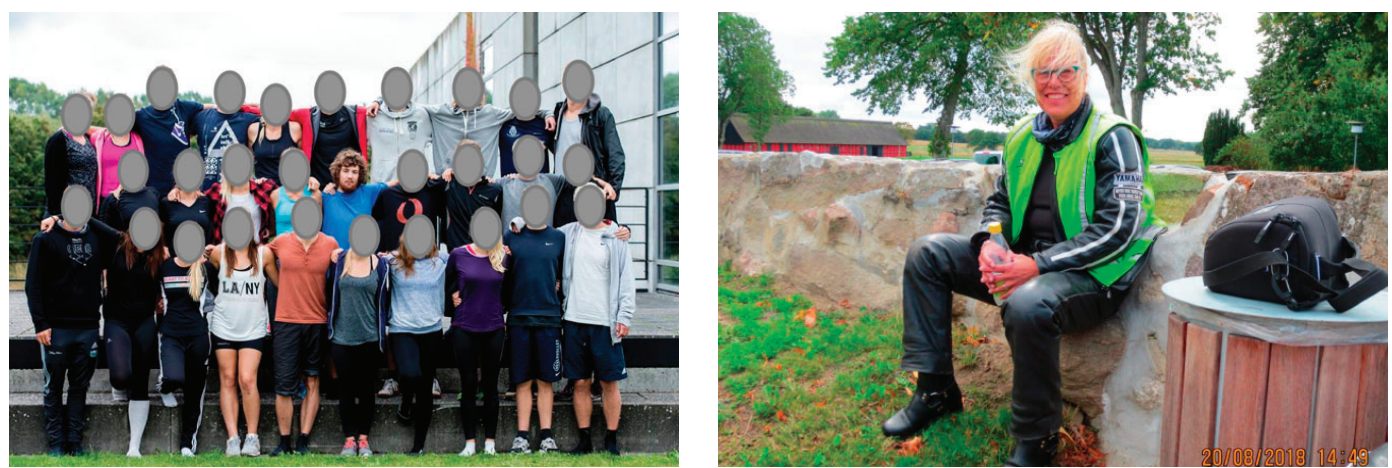

Susanne fortoeller: "Men lige nøjagtigt et billede som det her, øh, jeg har haft en kritisk sygdom, livstruende, og der brugte jeg motorcyklen, og jeg har sparket på rigtig mange kirkemure [hendes stemme er lige ved at knoekke over], men, øh, for mig er det en frihed, og det viser, at jeg kan selv bestemme, at jeg kan tage den her [motorcykel] og køre og komme videre, og man kan finde en styrke i sig selv (...)" I opgaven skrev Susanne bl.a.: "Her er et visuelt bud på, hvad livskvalitet, identitet og foellesskab er for mig. Jeg finder stor glcede ved, at jeg kan køre på motorcykel, det er en del af min identitet. Her finder jeg gode oplevelser i frellesskab med mand og venner, $i$ både ind- og udlandet. Jeg nyder følelsen af noerhed til naturen, dens dufte, vejens sving og vejrets luner. Jeg hviler i mig selv, her er kun vejen og mig."

Kroppen og personen bag ordene oplevede jeg også på en anden måde. Til fremlæggelsen fortalte Maria meget synlig berørt med afsæt i et privatfoto af sig selv. På fotografiet står hun med et spørgsmålstegn på et stykke papir i hånden foran et billede af sin familie, som hun havde malet $\mathrm{i}$ en svær periode af sit liv.

I opgaven skrev hun: "Billedet har en stor betydning for mig, da det var en del af en proces, der handlede om at forstå, hvem jeg var, og hvad min familie

2 Affektion, fra latin affectio (genitiv -onis), af adficere 'bevæge, gøre indtryk på' (Den Danske Ordbog). 


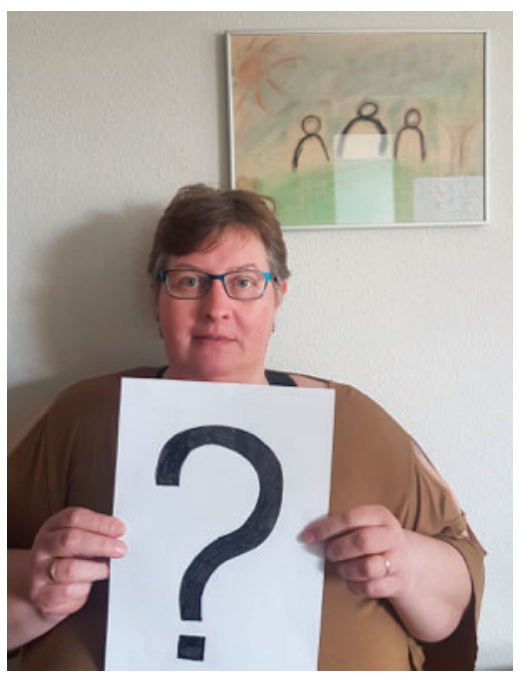

betød for mig, og hvordan min familie påvirkede mig $i$ den periode, hvor jeg havde min depression. Hvor meget det betød for mig, at min familie var der for mig, støttede og bakkede mig op." Da jeg i analyseprocessen efter fremlæggelsen læste opgaverne igennem, lagde jeg tydeligt mærke til, at jeg læste og hørte ordene med Marias stemme, som om hun læste dem op for mig. Jeg kunne tydeligt mærke, at den mening, jeg dannede ud af ordene, var stemt af hendes stemme og de erfaringer, der ligger bag. Ordene syntes simpelthen temmelig konkret at få krop og med denne krop en dybere eksistentiel mening. Det sker sjældent i mere konventionelle opgaver, hvor de studerende ikke er så personligt til stede. Dette er interessant ud fra et undervisningsperspektiv med fokus på dannelse, fordi det kan fortolkes som et udtryk for, at den studerende selv er til stede i ordene og med afsæt i sin egen eksistens forsøger at gøre sig begreb om livet. Det er også metodisk interessant ud fra et forskerperspektiv, fordi det kan fortolkes som en bekræftelse af, at det er muligt at undersøge den betydning, som de studerende lægger i ordene, med afsæt i den resonans, som de skaber i forskerkroppen, hvis de først en gang har været læst op.

At de studerende blev berørt af fortællingerne og billederne blev bekræftet af en efterfølgende "kommunikativ validering" (Kvale, 1997, s. 241). Jeg bad de studerende om at vurdere, om de kunne genkende min beskrivelse af, hvad der skete under fremlæggelserne med Pædagogiske billeder. De studerende sagde bl.a.: "Vi kommer ud af vores hoved og ned $i$ vores krop, man moerker sine folelser", "det [følelserne] smitter i rummet", og "man bliver berørt af andres følelser".

\section{Dannelse som en selvbiografisk proces, der forbinder det partikulcre og almene}

Det næste fotografi viser Cille (til højre i billedet) sammen med sin medstuderende, Anja, under en tredages friluftstur på modulet Natur og udeliv. De har lige været ude at bade. Cille: "Ja, og så er der lige sådan et fint billede her, der, for jer, der bare lige ser det, måske ikke viser scerligt meget, øh, andet end bare lige os, men for mig, når jeg ser det her billede, så fortceller det, eller så får jeg sådan følelserne indeni, som personligt har rigtig meget med identitet at gøre, og foellesskab og livskvalitet at gøre."

Det er kendetegnende for arbejdet med privatfotografier, at de studerende får en fornemmelse eller følelse i kroppen, som de formår at koble til de fagbegreber, vi arbejder med på modulet. De mærker begrebernes betydning, fordi de kan relatere dem til erfaringer, de har gjort på egen krop. Samtidig bliver de ikke stå- 


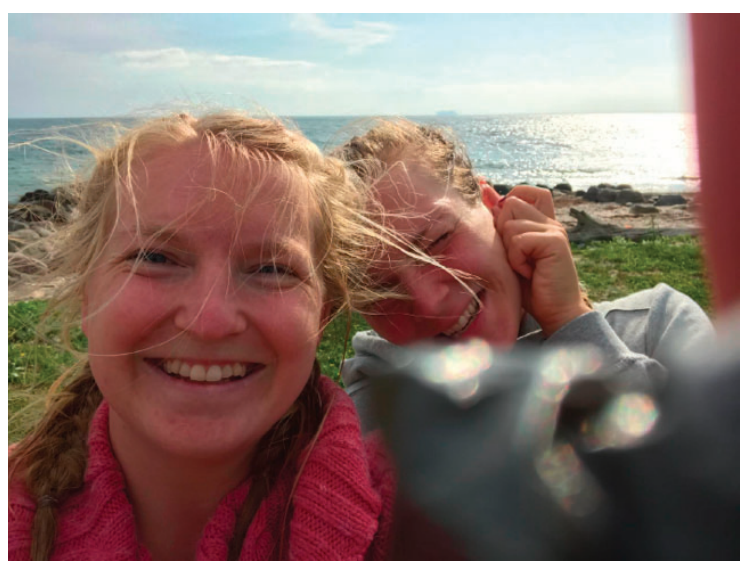

ende ved noget blot og bart privat og individuelt. Med afsæt i de konkrete livserfaringer og den stemthed, de har affødt, forsøger de at forstå det alment menneskelige, altså hvad fx livskvalitet, at være sig selv og fællesskab egentlig betyder. Fænomenologisk betragtet er det ikke den private og individuelle følelse i sig selv og den person, der har den, der er det interessante. Det, vi i undervisningen sammen forsøger at forstå, er det almene i det fænomen, som har fremkaldt den følelsesmæssige stemthed. Der er ikke tale om psykologisk introspektion. Forudsætningen for at nå til det almene er dog, at man taler ud fra en virkelig levet erfaring af fænomenet, som har sat sig spor i kroppen (Hansen, 2013, 2016). Det synes også at være noget af det, der sker, når de studerende taler om fællesskab og identitet med afsæt i Pædagogiske billeder. Denne form for tale kan også karakteriseres som en selvbiografisk dannelsesproces (Løvlie, 2009), hvor den studerende forsøger at skrive "seg inn en plass i det samfunnet og den kulturen man vokser opp i" (Løvlie, 2009, s. 27). Selvbiografien "forteller i førstepersons form om møter med objektive realiteter i familien, skolen og samfunnet" og handler om, "hvordan subjektet forener sin personlige historie med den allmenne historien"

(ibid., s. 29). Hermeneutisk betragtet sker der altså i det selvbiografiske arbejde med Pædagogiske billeder en formidling "mellem den enkeltes livshistorie og den historiske og samfundsmæssige kontekst for historien" (Hansson, 2015, s. 109).

Fænomenologisk forskning (Nielsen, 2017) har peget på, at pædagogstuderende kan bruge fortællinger om svære tider og personlige udfordringer konstruktivt i dannelsen af både deres personlige og professionelle identitet, fordi de virker eksistentielt meningsskabende. Rosa forbinder interessant nok også resonansoplever med "en meningsindstiftende sammenhæng. De momenter i mit liv, som lykkes, er dem, hvor jeg pludselig erindrer noget fortidigt og deraf får et blik på fremtiden" (Rosa, 2017, s. 34). Et eksempel på det kunne være, da Cille i et tilbageblik videre fortæller, hvor svært det var for hende at overvinde sin "enorme frygt for kryb og vand", som begrænsede hende og gik ud over hendes livskvalitet: "[...] ofte måtte [jeg] trcekke mig fra foellesskabet og følte mig utilstrcekkelig og udenfor. I månederne på modulet udviklede jeg mig enormt personligt [...]". Fortællingen er udtryk for et møde med verden, der har berørt og forandret hende. Hun har gjort "et verdensudsnit til sit eget" (Rosa, 2017, s. 28) og kan derfor fra et personligt møde med fænomenerne udtale sig om, hvad personlig udvikling er, og hun kan gøre det på en måde, så andre bliver berørt og lytter. 


\section{Diskussion: Man må have kroppen med for at kunne komme til forståelse og for at danne sig}

Kun når de studerende er til stede i ordene og i samtalen som personer; som subjekter, dvs. med deres egen krop og historie, kan de egentlig tage ansvar for det, de siger. Kun dér kan de nemlig undersøge og tage stilling til, hvad de værdier, som ordene er forbundet med, egentlig betyder, og hvordan ordene da kan bruges. I den proces bliver det samtidig klart, at spørgsmålet om betydningen af et ord ikke kan besvares endeligt, men må holdes åbent, fordi vores erfaringer med dem er forskellige: "Ord findes i et semantisk fletværk, der er kollektivt af indhold, men altid individuelt af form" (Kirkeby, 2016, s. 51). Ud fra en hermeneutisk betragtning kan man sige, at forståelse er noget, vi kommer til forskellige steder fra (Gadamer, 2004, s. 282; Hansen, 2013, s. 126), fx har vi hver især mødt og oplevet fænomenet fællesskab på forskellige måder. Det er ikke bare en vigtig erkendelsesmæssig pointe, men også en etisk og dannelsesmæssig: At undersøge og tage stilling til, hvad de værdier, som ordene gemmer på, egentlig betyder, er også forbundet med at undersøge og lytte til, hvad de betyder for andre. Og jeg har argumenteret for, at en væsentlig del af denne lytning foregår som interkropslig resonans, hvorigennem de følelser og kropslige fornemmelser, der knytter sig til erfaringer af fx fællesskab og angst, forplanter sig til den, der lytter.

Dette er selvsagt også en meget væsentlig pointe i forhold til de studerendes fremtidige møde med børn og borgere i pædagogisk praksis. De studerende må dér spørge sig selv og med hele deres krop lytte til, hvorfra barnet eller borgeren er kommet til forståelse af det, som samtalen drejer sig om, det være sig fx venskab, familie, retfærdighed eller selvbestemmelse. At forstå et andet menneske bliver da også at lytte til kroppens historie, som den fx kommer til udtryk i stemmen, i blikket og i kropssproget i det hele taget - ordene må få krop og fylde fra den person, der udtaler dem. Ellers glemmer vi måske, at der er et menneske bag dem. Arbejdet med Pædagogiske billeder kan i det perspektiv forstås som en form for resonanspædagogik, der forsøger at vække den "resonansfølsomhed" (Rosa, 2017, s. 32), der er nødvendig for på uddannelsen og i pædagogisk praksis at kunne "indtræde i resonans med en anden" (ibid.). Arbejdet med Pædagogiske billeder bidrager til at fremme en sproglighed og en samtale, som på én og samme tid er åben og etisk retningsgivende. Den er der både brug for på uddannelsen og i mødet med børn og borgere i pædagogisk praksis.

\section{Etiske og didaktiske refleksioner}

I eksemplerne i artiklen er det tydeligt, at de studerende giver meget af sig selv. Kan de ligefrem komme til at udlevere sig selv? Relationen mellem underviser og studerende og de studerende indbyrdes må tages i betragtning. Er der en tilstrækkelig grad af gensidig respekt og åbenhed, eller vil det kunne være en ubehagelig oplevelse, hvis man er usikker på, hvordan de andre studerende vil tage imod det, 
man viser af sig selv? Jeg har en enkelt gang oplevet, at der blandt nogle studerende ikke var resonans, men en grad af afvisning; at de ikke lod sig berøre. Dér var det vigtigt, at jeg som underviser var til stede og nærværende og kunne møde de studerende i deres fortællinger og følelser.

For at undgå at presse de studerende og ufrivilligt gøre dem for sårbare, har det været vigtigt at give dem mulighed for at løse opgaven på forskellige måder, bl.a. ved at vælge fotografier, som nok viser noget personligt oplevet, men ikke bliver for personlige eller private. Én studerende har således fx valgt en video af en danseopvisning på en efterskole, som hun fandt interessant i forhold til det fællesskab, der opstod mellem de dansende og publikum og indbyrdes mellem forældrene blandt publikum. En anden studerende havde udvalgt billeder af situationer i pædagogisk praksis, som havde gjort indtryk på hende. En tredje havde taget et billede af et træ og gjort sig nogle fine refleksioner over træet som billede på menneskelige relationer. Endelig var det ikke et krav, at de studerende skulle bruge privatfotografier. De kunne også inddrage andre æstetiske produkter, fx et digt, et maleri eller musik. Langt de fleste valgte dog privatfotos.

Det er relevant at reflektere over, om det kræver en særlig relation til de studerende at arbejde med privatfotografier med et meget personligt indhold. Måske er det en forudsætning, at man er parat til at gå foran og sætte faglige teorier og idéer om det at være menneske i relation til ens eget liv. Det gør jeg ofte. Efter fremlæggelsen mindedes vi, at jeg engang også viste dem en sammenklipning af privatfotos og private videoer tilsat min egen musik. Det var i forbindelse med en introduktion til, hvordan man gennem æstetiske udtryk kan arbejde med livshistorier. Jeg bemærker: ”Det var jo så lidt af min livshistorie, jeg fortalte jer."Måske det også har bidraget til at skabe en fælles forståelse for og oplevelse af, at det, vi med Pædagogiske billeder taler om, bare er livet - og at undervisning er mest meningsfuld, når det er det, vi gør.

Det er også relevant at være opmærksom på, at der i en eller anden forstand altid er en form for strukturel magt i en undersøgelsesramme, hvor den ene part; underviserne, synes at have monopol på at vurdere den anden; de studerende. Jeg anerkender den magt, der er forbundet med at tildele karakterer, men de studerende modtog ikke karakterer for deres deltagelse i undervisningen - først i forbindelse med en skriftlig prøve efter modulet. Desuden har de studerende også mulighed for at vurdere underviserne og udøve en form for modmagt i forbindelse med de anonyme digitale evalueringer, som gennemføres i forbindelse med afslutningen af ethvert modul.

\section{Konklusion}

I artiklen har jeg undersøgt, hvordan studerende på pædagoguddannelsen kan udvikle et kropsligt stemt og derfor i eksistentiel forstand meningsfuldt sprog ved at fortælle om egne livserfaringer med afsæt i privatfotos. I analysen har jeg vist, hvordan abstrakte ord som fx fællesskab, livskvalitet, frihed og dannelse bliver 
stemt af de studerendes egne livserfaringer, når de i undervisningen med afsæt i privatfotos fortæller om væsentlige hændelser i deres eget liv. Den kropsfænomenologiske analyse peger på, at stemtheden kommer til udtryk i deres kropssprog, fx i stemme og ansigtsmimik, og forplanter sig til tilhørerne gennem interkropslig resonans. Dermed synes der i undervisningsrummet at opstå en form for samstemthed, som giver den faglige samtale mening og substans.

Jeg har dermed ydet et forskningsmæssigt bidrag til forståelsen af, hvordan pædagogstuderende i højere grad, end det nu er tilfældet, kan få mulighed for at øve sig i at være til stede i ordene og i samtalen som personer; som subjekter, dvs. med deres egen krop og historie. Det gør det ikke alene muligt at finde sin egen stemme. Det gør det også muligt at erfare, at forståelse hermeneutisk betragtet er noget, vi kommer til forskellige steder fra. Vi har fx hver især mødt og oplevet fænomenet fællesskab på forskellige måder. Det er ikke bare en vigtig erkendelsesmæssig pointe, men også en etisk og dannelsesmæssig: At undersøge og tage stilling til, hvad de værdier, som ordene er behæftet med, egentlig betyder, er også forbundet med at undersøge og lytte til, hvad de betyder for andre. Det er ikke bare en vigtig pointe i forhold til deres egen dannelsesproces. Det er også en vigtig etisk pointe $\mathrm{i}$ forhold til deres kommende møde med børn og borgere i pædagogisk praksis.

\section{Litteratur}

Biesta, G.J.J. (2011). God uddannelse i målingens tidsalder - etik, politik, demokrati. Århus: Forlaget Klim.

Biesta, G.J.J. (2013). Demokratiloering $i$ skole og samfund - uddannelse, livslang loering og medborgerskabets politik. Århus: Forlaget Klim.

Biesta, G.J.J. (2017). Letting art teach, Art education 'after' Joseph Beuys. Arnhem: ArtEZ Press.

Biesta, G.J.J. (2018). Undervisningens genopdagelse - progressive argumenter for en konservativ ide. Århus: Forlaget Klim.

Bille, T., Nielsen, A., Jørgensen, B.O. \& Holand, D.A. (2017). Dannelsen af det pædagogiske blik i et livshistorisk perspektiv. Forskning i Pcedagogers Profession og Uddannelse, 1(1), 55-68.

Fuchs, T. (2013). The phenomenology of affectivity. I: Fulford, B., Davies, M., Graham, G., Sadler, J. \& Stanghellini, G. (eds.), The Oxford Handbook of Philosophy and Psychiatry (pp. 612-631). Oxford: Oxford University Press.

Fuchs, T. (2016). Das Gehirn - ein Beziehungsorgan: Eine phänomenologisch-ökologische Konzeption. Stuttgart: W. Kohlhammer GmbH.

Fuchs, T. (2016b). Intercorporeality and Interaffectivity. Phenomenology and Mind, 11, 194-209.

Gallagher, S. (2011). In defense of phenomenological approaches to social cognition: Interacting with the critics. Review of Philosophy and Psychology, 3(2), 187-212.

Gadamer, H.-G. (2004/1960). Sandhed og metode. Århus: Systime.

Hansen, F.T. (2013). Dannelse forstået som taktfuldhed over for 'det sande og det gådefulde' i tilværelsen. I: Pahuus, M. (red.), Dannelse i en loeringstid. Aalborg: Aalborg

Universitetsforlag.

Hansson, B. (2015). Bare skør-normal. En analyse af en brugerstøttet praksis i psykiatrien. En udgivelse i serien Afhandlinger fra Forskerskolen i Livslang Læring. Roskilde: Roskilde Universitet. 
Harboe, T. (2006). Indføring $i$ samfundsvidenskabelig metode (4. udgave). Frederiksberg: Samfundslitteratur.

Jørgensen, D. (2015). Ncervœer og eftertanke. Mit pæedagogiske laboratorium. Skive: Forlaget Wunderbuch.

Jørgensen, D. (2006). Skønhed. En engel gik forbi. Århus: Aarhus Universitetsforlag.

Kirkeby, O.F. (2016). Protreptik, selvindsigt og samtalepraksis. Frederiksberg: Samfundslitteratur.

Knudsen, L.E.D. (2008). Dannelse kommer fra kroppen: skitse til en dannelsesteori inspireret af Merleau-Ponty. I: Knudsen, L.E.D. \& Andersson, M. (red.), Skab dig!: pcedagogisk Filosofi (s. 79-102). København: Unge Pædagoger.

Kvale, S. (1997). InterView. En introduktion til det kvalitative forskningsinterview. København: Hans Reitzels Forlag.

Lindseth, A. (2009). Dannelsens plass i profesjonsutdanninger. Kunnskap og dannelse foran et nytt århundre, Innstilling fra Dannelsesutvalget for høyere utdanning. Universitetet i Bergen. Hentet d. 01.09.21: dannelsesutvalget.pdf

Løvlie, L. (2009). Dannelse og profesjon. Kunnskap og dannelse foran et nytt århundre, Innstilling fra Dannelsesutvalget for høyere utdanning. Universitetet i Bergen. Hentet d.01.09.21: http:// www.uib.no/filearchive/innstilling-dannelsesutvalget.pdf

Nielsen, A. (2019). Biestas begreb om subjektivering forstået som en "tilstand af dialog" -undervisning, ansvar og demokrati. Kognition \& Poedagogik 29(114), 96-105.

Nielsen, A. (2017). Sammenhængen mellem udvikling af resiliens og professionsidentitet blandt pædagogstuderende ved hjælp af livshistorier. Kognition og Poedagogik, 27(103), 58-70.

Rasmussen, K. (2018). Visuel etnografi. I: Jacobsen, M.H. \& Jensen, H.L. (red.), Etnografier. København: Hans Reitzels Forlag.

Rilke, R.M. (2001). Breve til en ung digter og anden prosa. Roskilde: Batzer \& Co.

Rosa, H. (2016). Resonanz: Eine Soziologie der Weltbeziehung. Frankfurt am Main: Suhrkamp.

Rosa, H. \& Endres, W. (2017). Resonanspcedagogik - når det knitrer i klassevcerelset. København: Hans Reitzels Forlag.

Rothuizen, J.J. (2015) På sporet af pcedagogisk faglighed, Poedagoguddannelsens deltagelse $i$ det poedagogiske projekt. Danmarks institut for Pædagogik og Uddannelse, Aarhus Universitet. Hentet d. 01.09.21: https://viauc.academia.edu/janjaaprothuizen

Rödel, S.S. \& Brinkmann, M. (2018). Theory and methodology of pedagogicalphenomenological video analysis. Video Journal of Education and Pedagogy, 3, 10.

Schmidt, C. (2007). Fra poedagogstuderende til poedagog: livshistoriens potentiale til at forstå læring som subjektiv tilegnelse. Forskerskolen i Livslang Læring. Roskilde: Roskilde Universitetscenter.

Schou, L.R. (2013). Kritisk-konstruktiv pædagogik og didaktik. I: Qvortrup, A. \& Wiberg, M. (red.), Lceringsteori \& didaktik. København: Hans Reitzels Forlag.

Togsverd, L. \& Rothuizen, J.J. (2020). Hvordan danner poedagogstuderende professionsidentitet $i$ (den ny) pcedagoguddannelse(n)? Århus: DPP.

Togsverd, L. \& Rothuizen, J.J. (2013). På vej mod en udviklingsbaseret pædagoguddannelse? I: Rothuizen, J.J. \& Togsverd, L. (red.), Hvordan uddannes pcedagoger? Perspektiver fra et forskningsprojekt. Århus: Videncenter for socialpædagogik og socialt arbejde, VIA UC. 